\title{
Covid-19 and its Impact on Human Life: An Empirical Study
}

\section{OPEN ACCESS}

Manuscript ID:

ASH-2020-08013288

Volume: 8

Issue: 1

Month: July

Year: 2020

P-ISSN: 2321-788X

E-ISSN: 2582-0397

Received: 20.06.2020

Accepted: 29.06.2020

Published: 02.07.2020

Citation:

Konanki, Sai Charan, and

K. Dasaratharamaiah.

"Covid-19 and Its Impact

on Human Life: An

Empirical Study." Shanlax

International Journal

of Arts, Science and

Humanities, vol. 8, no. 1 , 2020, pp. 61-78.

DOI:

https://doi.org/10.34293/

sijash.v8i1.3288

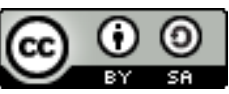

This work is licensed under a Creative Commons Attribution-ShareAlike 4.0 International License

\section{Sai Charan Konanki}

Data Scientist, School of Public Health, Harvard University, Boston, USA

\section{K Dasaratharamaiah}

Professor, Department of Economics and Applied Economics

Sri Krishnadevaraya University, Ananthapuramu, Andhra Pradesh, India

https://orcid.org/0000-0002-5447-1153

\begin{abstract}
Amid COVID-19 or Coronavirus outbreak, India has been hit by many major outbreaks since the earliest days, as SARS outbreak, swine flu outbreak, HIV/AIDS, Dengue and Chicken Gunya etc. But none of the outbreak was as widespread and as fatal as COVID-19. In this article, we have to discuss about the major outbreaks in the World in general and in India in particular which have been occurred and caused for the severe death tolls over a period of time. By introducing the history of various epidemic and pandemic diseases, then we have to focus mainly on the impact of COVID-19 on the human life among the selected respondents through a well-designed questionnaire. The data has been collected through online. The online questionnaire has been circulated to around 500 persons of various occupations and received from 287 persons. The data has been tabulated and analysed in the following pages. The main purpose of the study is, how the people responded for Prime Minister of India, Sri Narendra Modi on lock-down as well as maintaining social distance, using Masks along with the socio-economic factors influenced by COVID-19 during the lock-down period. The data has been collected during the third phase lock-down period in India.
\end{abstract}

Keywords: Corona Virus, COVID-19, Sanitizer, Masks, Lockdown and Social Distance

\section{Introduction}

The name, coronavirus, is derived from Latin corona, meaning crown or wreath or halo. Due to their crown-like projections on the surfaces coronaviruses got their name. The virus resembles like a crown when viewed under an electron microscope. The word was first used in print in 1968 by an informal group of virologists in the journal Nature to Designate the New Family of Viruses. The investigations by Chinese authorities have identified human cases with onset of symptoms in early December 2019. While some of the earliest known cases had a link to a wholesale food market in Wuhan, some did not. Officials confirm a case of COVID-19 in Thailand, the first recorded case outside of China.

Coronaviruses are a group of related RNA viruses that cause diseases in mammals and birds. In humans, these viruses cause respiratory tract infections that can range from mild to lethal. Mild illnesses include some cases of the common cold, which is caused also by certain other viruses, predominantly rhinoviruses, while more lethal varieties can cause SARS, MERS, and COVID-19. The new coronavirus is a respiratory virus which spreads primarily through droplets generated when an infected person coughs or sneezes, or through droplets of saliva or discharge from the nose. The virus can cause a range of symptoms, ranging from mild illness to pneumonia. Symptoms of the disease are fever, cough, sore throat and headaches. In severe cases difficulty in breathing and deaths can occur. Still the world has not been found the new vaccines or antiviral drugs to prevent or treat human corona virus infections. 
Amid COVID-19 or Coronavirus outbreak, India has been hit by many major outbreaks since the earliest days, such as SARS outbreak, swine flu outbreak, HIV/AIDS, Dengue and Chicken Gunya etc. But none of the outbreak was as widespread and as fatal as COVID-19. In this article, we have to discuss about the major outbreaks in the World in general and in India in particular which have been occurred and caused for the severe death tolls over a period of time. By introducing the history of various epidemic and pandemic diseases, then we have to focus mainly on the impact of COVID-19 on the human life among the selected respondents through a well-designed questionnaire. The data has been collected through online. Thev online questionnaire has been circulated to around 500 persons of various occupations and received from 287 persons. The data has been tabulated and to $\mathrm{b}$ e analysed in the following pages.

\section{Need and Importance of the Study}

In this backdrop, the present study is focussed on the impact of COVID-19 during the lockdown period in India in general and in the study area in particular. For this purpose, the data has been collected through a well-designed schedule from the selected people from various categories by mailing a questionnaire online. The collected online data has been analysed and presented below. About 287 people are responded for the questionnaire. The respondents are categorised as government. employees, private employees, business persons and others (Retired employees, contractors, housekeepers, students and scholars are come under this category).

The main purpose of the study is, how the people responded for Prime Minister of India, Sri Narendra Modi on lock-down as well as maintaining social distance, using Masks along with the socio-economic factors influenced by COVID-19 during the lockdown period. The data has been collected during the second lock-down period in India.

\section{Objectives of the Study}

The major objectives of the present study are as follows.

- To examine the origin and history of epidemics and pandemics in the world and in India
- To describe the spread of COVID-19 in various parts of the country

- To assess the opinion of public on the awareness in preventing COVID-19

- To analyse the impact of Lock-Down on the public

- To assess the income levels and food habits of the people before and during COVID-19.

\section{Origin and History of Pandemic Diseases}

The origin and history of pandemic diseases are discussed in the following lines. As humans have spread across the world, so have infectious diseases. The diseases and illness have plagued humanity since the earliest days. The widespread trade created new opportunities for human and animal interactions with one country to other. The more civilized humans became with larger cities, more exotic trade routes and contact with different populations of people, animals and ecosystems, the more likely pandemics would occur. The following are some of the major pandemics that have been occurred over a period of time from very early years to the present days in the world and in India.

The widespread Antonina Plague during 165180 , believed to be either smallpox or measles and caused for the death toll of around 5 million population in the world. The Japanese smallpox is one of the epidemic disease entered in the human in 735 and continued for a period of 2 years. It is a Variola major virus and caused for the death toll of one million population. The plague of Justinian was spread to the human during 541-542. It origins from Yersinia pestis bacteria through rats and fleas and caused for the death of 30 to 50 million population. The Black Death, a Bubonic plague with Yersinia pestis bacteria occurred during 1347-1351 and caused for the death of 200 miliion population.

The New World Smallpox Outbreak during 1520 onwards caused for the death of 56 million population. The origin of this outbreak is a Variola major virus. Great Plague of London in 1665 (Yersinia Pestis bacteria/rats and fleas) damaged the life of 1,00,000 population. The Italian Plague of 1629-1631 (Yersinia Pestis bacteria/rats and fleas) also caused for the death of one million population. The Cholera Pandemics in 1923 (V. Cholera bacteria), caused for 
the death of another million plus population. The third world Plague (Yersinia Pestis bacteria / rats and fleas) was another outbreak in India and China and caused for the death of 12 million population in the two countries. The yellow fever during late $1800 \mathrm{~s}$ in USA, a virus from mosquitoes happened with a death toll of $1,00,000$ to $1,50,000$ population in USA. The Russian Flu, believed to be H2N2 (avian origin) during 1889-1890 caused for the death toll of one million population.

Encephalitis Lethargica is also known as lethargic encephalitis. It was an epidemic and spread around the world between 1915 -1926. Encephalitis Lethargica was an acute contagious disease where the virus attacked the central nervous system of human beings. Encephalitis Lethargica was in its epidemic form in Europe but it was still sporadic in India. While the world was still fighting with Encephalitis Lethargica, a new virus spread out and was known as Spanish Flu. Spanish flu (1918-1920) was caused by the deadly strain of avian influenza and was spread due to World War I, an origin from H1N1 virus through pigs was caused for a death toll of 40- to 50 million population. The Asian Flu of 1957-1958 with H2N2 virus makes a death toll of 1.1 million human population.

The Hong Kong Flu of 1968-1970 due to the H3N2 strain of influenza, a virus and within two months it reached India (1968-69). American soldiers returning from Vietnam after the Vietnam War became the carrier of this virus to the US. It caused for the death toll of another one million population. The HIV/AIDS disease entered in the human from 1981 and makes a death toll of 25 to 35 million population as on today in the world. Swine Flu during 2009-2010 was caused for the death of 2,00,000 population which originated from H1N1 virus through pigs. Smallpox (1974) was caused by either of the two virus variants, Variola major or Variola minor. According to the reports, $60 \%$ of the smallpox cases globally were reported in India and was more virulent as compared to other parts of the world.

The pneumonic plague (1994), hit Surat and people fled from the city in large numbers. Rumours along with the misinformation worsen the situation and people hoarded the essential supplies. The mass migration from Surat to other parts of the country spread the disease across India. The main cause of the Plague was unhygienic conditions in the city such as open drains, poor sewage system etc. After the 21st century, SARS (2002-2004) was the first severe disease which was transmissible from one person to another. It was a severe acute respiratory syndrome and the cause of SARS was similar to COVID-19, named SARS CoV. This virus was known for frequent mutations and was transmissible from one person to another and through coughing and sneezing.

Dengue and Chikungunya (2006), outbreak both were mosquito-borne typical diseases and stagnation of water in different parts of the country provided breeding grounds for these mosquitos. It affected people across India. Several parts of the country were impacted due to these outbreaks and the highest number of patients were reported in the national capital i.e., Delhi. Many people in Gujarat were infected with Hepatitis B (2009), which caused by the transmission of the infected blood and other body fluids. Odisha witnessed the outbreak of Jaundice (2014 -2015) and the main cause was suspected to be the contaminated water. As per the reports, the drain water seeped through pipelines of drinking water making it unhealthy for drinking.

During the end months of 2014, several reports of the H1V1 virus started to rise. Swine flu is a type of influenza virus and in 2014, Gujarat, Rajasthan, Delhi, Maharashtra and Telangana were among the worst affected states due to the virus. Even after several public awareness drives, by March 2015, about 33,000 cases were reported across the country and about 2000 people lost their lives.

The city of Gorakhpur in Uttar Pradesh witnessed an increase in the number of deaths of children due to the Encephalitis outbreak through mosquito bites in 2017. These children died of Japanese encephalitis and acute encephalitis syndrome. Both of these viral infections cause inflammation of the brain which result in physical disabilities and even deaths in some cases. Nipah Virus outbreak (2018), an infection caused by fruit bats was reported in Kerala. Within a few days of its widespread of the virus, the state government implemented several protectionary measures in order to minimise the spread of the 
virus. Due to the preventive measures, by the month of June, the outbreak was curbed within Kerala.

\section{Coronavirus (COVID-19)}

Coronavirus disease (COVID-19) is a new strain that was discovered in 2019 and has not been previously identified in humans. It is zoonotic, thus can be transmitted between animals and people. Common signs of infection include respiratory symptoms, fever, cough, shortness of breath and breathing difficulties, loss of identifying the smell and taste. In more severe cases, the infection can cause pneumonia, severe acute respiratory syndrome, kidney failure and even death.Many pandemic outbreaks outbreaks have been eliminated from India with the help of proper hygiene and sanitization practices but COVID-19 still prevails in India as well as in other parts of the world.

As per the AIIMS, the infection spreads through respiratory route i.e. respiratory droplets and direct human contact. Healthcare personnel are at risk of infection through respiratory routes and direct contact with infectious patients. Health experts suggested people should use masks and wash their hands. Novel coronavirus displayed several other symptoms. The disease continues to spread in Asia and across the world. Not only this, Coronavirus can also spread between people which raised the possibility of increased transmissions.

It is said that coronavirus belongs to the same family as the SARS virus. The coronavirus disease is connected to a seafood market in China. According to WHO, a Chinese national travelling in Thailand was the first confirmed case of coronavirus infection outside China on 13th January 2020. The full genome of the new virus has been posted by the Chinese authorities and it has been named as 'novel coronavirus 2019' (nCoV-2019). As per the Center for Disease Control and Prevention which is closely monitoring an outbreak caused by a new coronavirus in Wuhan City, Hubei Province, China.

\section{Coronavirus and its History}

Coronavirus spreads in more than 200 countries and territories across the world and is declared a pandemic by the WHO in March 2020. The first case of novel coronavirus was identified in Wuhan, Hubei
Province, China. The WHO and other organisations named the new illness caused due to coronavirus as COVID-19 (Coronavirus Disease-2019). Prime Minister of India, Sri. Narendra Modi asked people to remain calm and advised to take some small yet important measures as a self-protection from the coronavirus.

\section{The Symptoms of Coronavirus Disease (COVID-19)}

- Fever

- Tiredness

- Dry cough

- Runny Nose

- Sore Throat

- Sneezing

- Exacerbated asthma

- Difficulty in breathing

- Aches and Pain

- Loss of identifying smell and taste

Sometimes people also report diarrhoea, pneumonia, bronchitis. It is common in people who have a weak immune system, in infants, older adults, etc.

\section{Treatment or How to Prevent an Infection}

- Regular hand washing

- During coughing and sneezing, cover mouth and nose

- Properly cooked meat and eggs

- Avoid contact from the person showing symptoms of respiratory illness

Therefore, we can say that there is no proper cure and treatments including taking care of yourself and over-the-counter (OTC) medication.

- Do proper rest and avoid overexertion

- Drink enough water

- Avoid smoking and smoky areas

- Take medicine to reduce pain and fever

- Use a clean humidifier or cool mist vaporiser Standard Precautions include basic hand hygiene, use of personal protective equipment, respiratory etiquettes, and environmental disinfection.

\section{Spread of Coronavirus Disease}

- While coughing and sneezing, an infection spread into the air and spread the virus 
- While touching or shaking hands with an infected person can also pass the virus

- Making in contact with a surface or object that has a virus and while touching nose, eyes or mouth

- Rarely, coronavirus may spread through contact with faces

\section{Survival Period of Coronavirus over the Surfaces or Objects}

It is not certain how long the virus of COVID-19 survives on surfaces. Some studies reveal including preliminary information on the COVID-19, virus may persist on surfaces for hours or up to several days. This may vary under different conditions like the type of surface, temperature or humidity of the environment. It is necessary to clean the surface or disinfectant to kill the virus and protect yourself and others. Clean your hands with soap and water and with an alcohol-based hand rub. Avoid touching your eyes, mouth, or nose. Therefore, we can say that coronavirus is a large family of viruses that cause illness from the common cold to more severe diseases.

\section{COVID-19 Cases in India}

To prevent the spread of COVID-19, Central and concerned state governments have taken steps to identify the COVID-19 cases and are conducting tests frequently. The following table 1 and diagram 1 revels the number of cases at all India level as on 18th June 2020. For the first 58 days 1,00,000 COVID tests were covered in the country as a whole. By 12th May 2,00,000 cases were tested and as on June 18th $20206,12,000$ cases were tested at all India level. The COVID-19 is affecting 219 countries and Territories in the world. At the global level, total COVID-19 cases are 87,57,750, (new cases-6760) with 22,97,190 cases, USA is in the first place and India is at 4th place with 3,95,812 cases as on 19th June 2020. At all India level, 3,95,812 cases are confirmed, 2,04,711 cases are recovered and 12,573 cases are deceased. In Andhra Pradesh, 7518 cases are confirmed, 3,789 cases are recovered and 92 are deceased. Currently infected cases at global level are $36,69,782$. Out of this, 36,14,989 are in mild condition and 54,793 are in serious or critical condition. The total number of closed cases at global level are 46,25,449 (91\%) and deaths are 4,62,519 $(9 \%)$

COVID-19 Pandemic Lockdown in India

Table 1: Number of COVID-19 Cases are tested as on 18-06-2020

\begin{tabular}{|c|c|}
\hline Testing period & No. of Cases Tested \\
\hline 30th April (58 days) & $1,00,000$ \\
\hline 12th May (12 days) & $2,00,000$ \\
\hline 23rd May (11 days) & $3,00,000$ \\
\hline 2nd June (10 days) & $4,00,000$ \\
\hline 10th June (8 days) & $5,00,000$ \\
\hline 17 th June (7 days) & $6,00,000$ \\
\hline 30th April (58 days) & $1,00,000$ \\
\hline
\end{tabular}

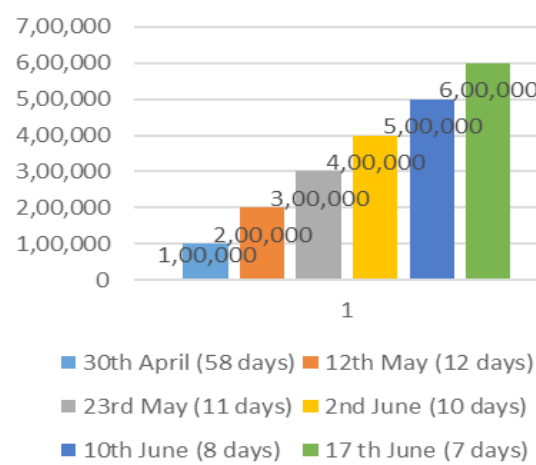

Source: Arogya Setu App

As per the direction of the Prime Minister Sri. Narendra Modi, a 14 hour Janata Curfew (people's Curfew) was followed in India to protest COVID-19 and to motivate the public to take preventive measures against COVID-19. All the Indians were followed the Modi's announcement for 14 hours Janata Curfew and this causes for a series of regulations in the country's COVID-19 affected regions in the country. The following are the phases of Lockdown followed in India as ordered by the Central government under the able leadership of the Prime Minister Sri Narendra Modiji to control the spread of COVID-19 pandemic in India.

- Phase I: 25th March 2020 - 14th April 2020 (21 days)

- Phase II: 15th April 2020 - 3rd May 2020 (19 days)

- Phase III: 4th May 2020 - 17th May 2020 (14 days) 
- Phase IV: 18th May 2020 - 31st May 2020 (14 days)

- Phase V: 1st June 2020 - ongoing (17 days), scheduled to end on 30th June 2020 (only for containment zones)

\section{Methods of Lockdown}

The following are various methods of following lockdown in India.

- Ban on people from stepping out of their homes

- All services and shops closed except pharmacies, hospitals, banks, grocery shops and other essential services

- Closure of commercial and private establishments (only work-from-home allowed)

- Suspension of all educational, training, research institutions

- Closure of all places of worship

- Suspension of all non-essential public and private transport

- Prohibition of all social, political, sports, entertainment, academic, cultural, religious activities

\section{Prohibitions during Lockdown Period}

The lockdown restricted people from stepping out of their homes. All transport services such as road, air and rail were suspended, with exceptions for transportation of essential goods, fire, police and emergency services. Educational institutions, industrial establishments and hospitality services were also suspended. Services such as food shops, banks and ATMs, petrol pumps, other essentials and their manufacturing are exempted.

\section{Relaxations in Lockdown}

From 4 May 2020, the lockdown was eased with several relaxations in all zones as per the guidelines of Ministry of Home Affairs.

\section{Impact of Lockdown}

The Food delivery services were banned by several state governments despite the central government's approval. Thousands of people emigrated out of major Indian cities, as they became jobless after the lockdown. Due to the lockdown, more than 350 deaths were reported with reasons ranging from starvation, suicides, exhaustion, road and rail accidents, police brutality and denial of timely medical care. Among the reported deaths, most were among the marginalised migrants and labourers.

\section{Empirical Analysis on the Impact of COVID-19 on the Public Life}

To examine the impact of COVID-19 and to know the behaviour and performance of the various sections of the society on the Lockdown measures by the Central and State governments, an empirical study has been conducted through online method and the results to be focussed in the following lines.

\section{Age-Wise and Occupation-Wise Distribution of Respondents}

The impact of COVID-19 on the public life, measures taken by the governments to prevent COVID-19, precautionary measures taken by the public for self-protection from COVID-19 such as changing food habits, wearing masks, using sanitizer and maintaining social distance, and problems faced during lockdown period are to be assessed in this paper with the help of collected data from 287 respondents from various parts of Andhra Pradesh and some from other parts of the country also.

Table 2: Occupation Wise Distribution of Respondents (in Years)

\begin{tabular}{|l|c|c|c|c|c|}
\hline Occupation & $<\mathbf{2 5}$ & $\mathbf{2 6 - 4 0}$ & $\mathbf{4 1 - 6 0}$ & $\mathbf{7 6 0}$ & Total \\
\hline Govt. & 12 & 51 & 66 & 11 & 140 \\
Employee & $(8.57)$ & $(36.43)$ & $(47.14)$ & $(7.86)$ & $(100)$ \\
\hline Private & 09 & 27 & 21 & 00 & 57 \\
Employee & $(15.79)$ & $(47.37)$ & $(36.84)$ & $(0.00)$ & $(100)$ \\
\hline Business & 02 & 04 & 05 & 03 & 14 \\
Persons & $(14.29)$ & $(28.57)$ & $(35.71)$ & $(21.43)$ & $(100)$ \\
\hline Others & 15 & 29 & 23 & 11 & 76 \\
& $(19.74)$ & $(38.16)$ & $(30.26)$ & $(14.47)$ & $(100)$ \\
\hline \multicolumn{1}{|c|}{ Total } & 38 & 111 & 115 & 25 & 287 \\
& $(13.24)$ & $(38.68)$ & $(40.07)$ & $(8.71)$ & $(100)$ \\
\hline
\end{tabular}

Source: Primary Data from Online Survey,

Note: Figures in parentheses indicates percentages

The occupation-wise and age-wise distribution of respondents is presented in table 2 and illustrated in diagram 2. It reveals that out of 140 government employees, $8.57 \%$ are in the age group of less than 25 years, $36.43 \%$ are between 26 and 40 years of age, 
$47.14 \%$ are in the age group of 41-60 years and the remaining $7.86 \%$ are in the above 60 years of age.

Figure 2: Occupation Wise Distribution of Respondents (in Years)

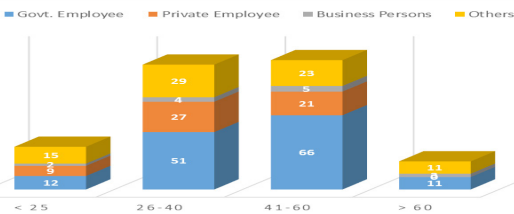

It may also noticed that out of 57 private employees under study, $15.79 \%$ are in the age group of less than 25 years of age, $47.37 \%$ are between 26 and 40 years of age, $36.84 \%$ are in the age group of between 41 and 60 years. It may also observed that out of 14 business persons, $14.29 \%$ are in the age group of less than 25 years, $28.57 \%$ are between 26 and 40 years, $35.71 \%$ are in the age group of 41.60 years and the remaining $21.43 \%$ are in the age group of above 60 years. Out of 76 respondents from other category such as retired employees, contractors, students and house wives etc., $19.74 \%$ are in the age group of less than 25 years, $38.16 \%$ are between 26 and 40 years of age, $30.26 \%$ are between 41 and 60 years of age and the remaining $124.47 \%$ are in the above 60 years of age.

\section{Gender-Wise Distribution of Respondents}

As shown in table 3 and diagram 3, out of 140 government employees under study, $82.14 \%$ are male and $17.86 \%$ are female. Out of 57 private employees under review, $68.42 \%$ are male and $31.58 \%$ are female. Out of 14 business people, $92.86 \%$ are male and only $7.14 \%$ are female. For others, $57.89 \%$ are male and $42.11 \%$ are female. For the total respondents, $73.52 \%$ are male and $26.48 \%$ are female under review.

Table 3: Gender Distribution of Respondents

\begin{tabular}{|l|c|c|c|}
\hline Occupation & Female & Male & Total \\
\hline $\begin{array}{l}\text { Govt. } \\
\text { Employee }\end{array}$ & $25(17.86)$ & $\begin{array}{c}115 \\
982.14)\end{array}$ & $140(100)$ \\
\hline $\begin{array}{l}\text { Private } \\
\text { Employee }\end{array}$ & $18(31.58)$ & $39(68.42)$ & $57(100)$ \\
\hline $\begin{array}{l}\text { Business } \\
\text { Persons }\end{array}$ & $01(7.14)$ & $13(92.86)$ & $14(100)$ \\
\hline Others & $32(42.11)$ & $44(57.89)$ & $76(100)$ \\
\hline \multicolumn{1}{|c|}{ Total } & $\mathbf{7 6 ( 2 6 . 4 8 )}$ & $\mathbf{2 1 1 ( 7 3 . 5 2 )}$ & $\mathbf{2 8 7 ( 1 0 0 )}$ \\
\hline
\end{tabular}

Source: Primary Data from Online Survey,

Note: Figures in parentheses indicates percentages

\section{Figure 3: Gender Distribution of Respondents}

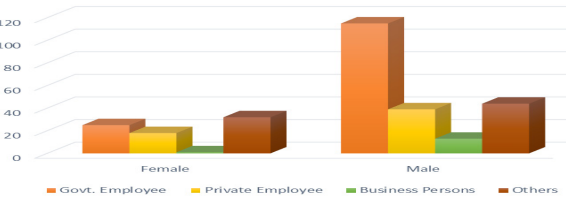

\section{Monthly Income Levels of Respondents}

As shown in table 4 and diagram 4, 10\% of government employees, $29.82 \%$ of private employees, $14.29 \%$ of business persons and $14.47 \%$ of others are in the income range of less than Rs.30,000 per month. About $14.29 \%$ of government employees, $28.07 \%$ of private employees, $21.43 \%$ of business persons and $32.89 \%$ of others are in the income range of Rs. 30,001 to 50,000. It may also noticed that $20.71 \%$ of government employees, $19.30 \%$ of private employees, $14.29 \%$ of business persons and $22.37 \%$ of others are in the income levels of Rs.50,001 to Rs.75,000.

Table 4 Monthly Income Levels of Respondents

\begin{tabular}{|l|c|c|c|c|c|c|}
\hline \multicolumn{1}{|c|}{ Occupation } & $<\mathbf{3 0 , 0 0 0}$ & $\mathbf{3 0 , 0 0 1 - 5 0 , 0 0 0}$ & $\mathbf{5 0 , 0 0 1 - 7 5 , 0 0 0}$ & $\mathbf{7 5 , 0 0 1 - 1 , 0 0 , 0 0 0}$ & $\mathbf{> 1 , 0 0 , 0 0 0}$ & Total \\
\hline Govt. Employees & $14(10.00)$ & $20(14.29)$ & $29(20.71)$ & $35(25.00)$ & $42(30.00)$ & $140(100)$ \\
\hline Private Employees & $17(29.82)$ & $16(28.07)$ & $11(19.30)$ & $08(14.04)$ & $05(8.77)$ & $57(100)$ \\
\hline Business Persons & $02(14.29)$ & $03(21.43)$ & $02(14.29)$ & $05(35.71)$ & $02(14.29)$ & $14(100)$ \\
\hline Others & $11(14.47)$ & $25(32.89)$ & $17(22.37)$ & $11(14.47)$ & $12(15.79)$ & $76(100)$ \\
\hline \multicolumn{1}{|c|}{ Total } & $44(15.33)$ & $64(22.30)$ & $59(20.56)$ & $59(20.56)$ & $61(21.25)$ & $287(100)$ \\
\hline
\end{tabular}

Source: Primary Data from Online Survey, Note: Figures in parentheses indicates percentages

About 25\% of government employees, $14.04 \%$ of private employees, $35.71 \%$ of business persons and $14.47 \%$ of others are in the income levels of Rs.
75,001 to Rs. $1,00,000$. About $30 \%$ of government employees, $8.77 \%$ of private employees, $14.29 \%$ of business persons and $15.79 \%$ of others are income 
range of above Rs. $1,00,000$. It may also observed that out of total respondents, $15.33 \%$ are in the income level of less than Rs.30,000, 22.30\% are in the income group of Rs.30,001 to Rs.50,000, 20.56\% of respondents are in the income group of Rs.50,001 to Rs.75,000, another $20.56 \%$ are in the income group of Rs.75,001 to Rs.1,00,000 and $21.25 \%$ of respondents in income group of above Rs. 1,00,000.

Figure 4: Monthly Income Levels of Respondents

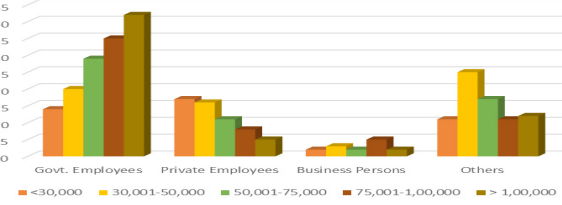

\section{Availing Moratorium on Bank Loans by Respondents}

As per the guidelines of Reserve Bank of India, all the Financial Institutes have been implemented 3 months Moratorium on various loans from March 2020 to June 2020 . Due to receiving $50 \%$ of the salary in Andhra Pradesh and Telangana states, many of the employees, business persons and others have been utilized this relief and the same is presented in the table 5 and diagram 5. It reveals that out of 287 respondents under review, $70.38 \%$ of respondents have been availed the Moratorium facilities on their loans. It shows that $67.14 \%$ of government employees, $75.44 \%$ of private employees, $64.29 \%$ of business persons and $73.68 \%$ of others are availing moratorium facilities on their loans.

Table 5: Availing Moratorium on Bank Loans

\begin{tabular}{|c|c|c|c|}
\hline Occupation & No & Yes & Total \\
\hline $\begin{array}{l}\text { Govt. } \\
\text { Employees }\end{array}$ & $\begin{array}{c}94 \\
(67.14)\end{array}$ & $\begin{array}{c}46 \\
(32.86)\end{array}$ & $\begin{array}{c}140 \\
(100)\end{array}$ \\
\hline $\begin{array}{l}\text { Private } \\
\text { Employees }\end{array}$ & $\begin{array}{c}43 \\
(75.44)\end{array}$ & $\begin{array}{c}14 \\
(24.56)\end{array}$ & $\begin{array}{c}57 \\
(100)\end{array}$ \\
\hline $\begin{array}{l}\text { Business } \\
\text { Persons }\end{array}$ & $\begin{array}{c}09 \\
(64.29)\end{array}$ & $\begin{array}{c}05 \\
(35.71)\end{array}$ & $\begin{array}{c}14 \\
(100)\end{array}$ \\
\hline Others & $\begin{array}{c}56 \\
(73.68)\end{array}$ & $\begin{array}{c}20 \\
(26.32)\end{array}$ & $\begin{array}{c}76 \\
(100)\end{array}$ \\
\hline Total & $\begin{array}{c}202 \\
(70.38)\end{array}$ & $\begin{array}{c}85 \\
(29.62)\end{array}$ & $\begin{array}{c}287 \\
(100)\end{array}$ \\
\hline
\end{tabular}

Source: Primary Data from Online Survey,

Note: Figures in parentheses indicates percentages
Figure 5: Availing Moratorium on Bank Loans

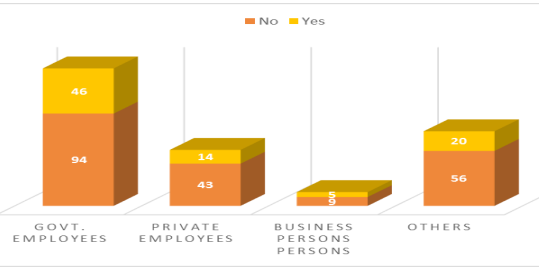

Following Lockdown to Prevent the Spread of COVID-19

As called by the Prime Minister of India, all the Indians are followed the lockdown from 25th March 2020 to 31 st May 2020 in 5 phases in the country as a whole. The data has been collected from all corners during 3rd Phase of lockdown period. It reveals that out of 140 government employees, $93.57 \%$ are followed the lockdown without any deviation and the remaining $6.43 \%$ are not followed strictly (table 6 and diagram 6). It shows that $98.25 \%$ of private employees, $100 \%$ of the business people and $97.37 \%$ of others are followed the lockdown strictly as per the government direction to protect from COVID-19.

Table 6: Following Lock-Down to Protect from Corona

\begin{tabular}{|l|c|c|c|}
\hline Occupation & Yes & No & Total \\
\hline $\begin{array}{l}\text { Govt. } \\
\text { Employee }\end{array}$ & $\begin{array}{c}131 \\
(93.57)\end{array}$ & $\begin{array}{c}09 \\
(6.43)\end{array}$ & $\begin{array}{c}140 \\
(100)\end{array}$ \\
\hline Private & 56 & 01 & 57 \\
Employee & $(98.25)$ & $(1.75)$ & $(100)$ \\
\hline Business & 14 & 00 & 14 \\
Persons & $(100)$ & $(0.00)$ & $(100)$ \\
\hline Others & 74 & 02 & 76 \\
& $(97.37)$ & $(2.63)$ & $(100)$ \\
\hline \multicolumn{1}{|c|}{ Total } & $\mathbf{2 7 5}$ & $\mathbf{1 2}$ & $\mathbf{2 8 7}$ \\
& $\mathbf{( 9 5 . 8 2 )}$ & $\mathbf{( 4 . 1 8 )}$ & $\mathbf{( 1 0 0 )}$ \\
\hline
\end{tabular}

Source: Primary Data from Online Survey,

Note: Figures in parentheses indicates percentages

Figure 6: Following Lock-Down to Protect from Corona

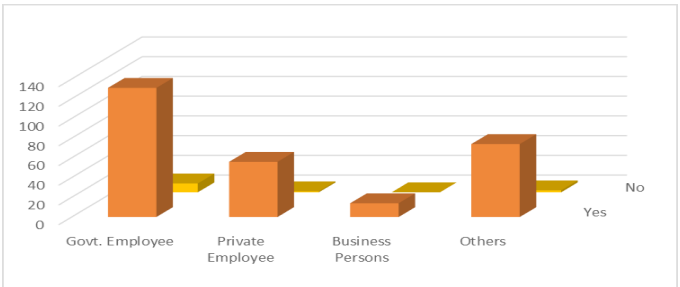

Yes $=$ No 
Following Social Distance to Protect from Corona by Sample Respondents

The behavior of the public in maintaining social distance outside the home or in the market places is observed and reveals that $95.71 \%$ of the government employees, $98.25 \%$ of the private employees, $92.86 \%$ of the business persons and $92.11 \%$ of others are informed that they are following social distancing in the market and public places to prevent themselves from the Corona virus (see table 7 and diagram 7). It may also noticed that $3.57 \%$ of government employees, $1.75 \%$ of private employees, $7.14 \%$ of business people, and $6.58 \%$ of others are partially followed the social distancing in the public places. Only $0.71 \%$ of government employees and $1.32 \%$ of others are not followed the social distancing due to their negligence in taking precautionary measures against COVID-19.

Table 7: Following Social Distancing to Protect from Corona Virus

\begin{tabular}{|l|c|c|c|c|}
\hline Occupation & Yes & Partially & No & Total \\
\hline $\begin{array}{l}\text { Govt. } \\
\text { Employee }\end{array}$ & $\begin{array}{c}134 \\
(95.71)\end{array}$ & $\begin{array}{c}05 \\
(3.57)\end{array}$ & $\begin{array}{c}01 \\
(0.71)\end{array}$ & $\begin{array}{c}140 \\
(100)\end{array}$ \\
\hline Private & 56 & 01 & 00 & 57 \\
Employee & $(98.25)$ & $(1.75)$ & $(0.00)$ & $(100)$ \\
\hline Business & 13 & 01 & 00 & 14 \\
Persons & $(92.86)$ & $(7.14)$ & $(0.00)$ & $(100)$ \\
\hline Others & 70 & 05 & 01 & 76 \\
& $(92.11)$ & $(6.58)$ & $(1.32)$ & $(100)$ \\
\hline \multicolumn{1}{|c|}{ Total } & $\mathbf{2 7 3}$ & $\mathbf{1 2}$ & $\mathbf{0 2}$ & $\mathbf{2 8 7}$ \\
& $\mathbf{( 9 5 . 1 2 )}$ & $\mathbf{( 4 . 1 8 )}$ & $\mathbf{( 0 . 7 0 )}$ & $\mathbf{( 1 0 0 )}$ \\
\hline
\end{tabular}

Source: Primary Data from Online Survey,

Note: Figures in parentheses indicates percentages

Figure 7: Following Social Distancing to Protect from Corona Virus

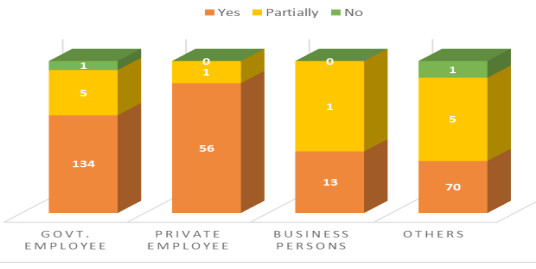

\section{Wearing Masks Outside the Home}

To protect from COVID-19, the experts as well as WHO and the Central and State governments are strictly instructed to wear the face masks outside the house as there is a possibility of spreading the Corona virus from one to others through droplets. By following this advice, most of the population in the world as well as in India are wearing face masks. In this background, it is observed that $95 \%$ of government employees, $98.25 \%$ of the private employees, $100 \%$ of business people and $88.16 \%$ of others under review are wearing face masks (table 8 and diagram 8). Out of total 287 respondents under study, $94.08 \%$ are wearing masks to protect from COVID-19.

Table 8: Using Mask outside the House

\begin{tabular}{|l|c|c|c|c|}
\hline Occupation & Yes & Rarely & No & Total \\
\hline Govt. & 133 & 05 & 02 & 140 \\
Employee & $(95.00)$ & $(3.57)$ & $(1.43)$ & $(100)$ \\
\hline Private & 56 & 01 & 00 & 57 \\
Employee & $(98.25)$ & $(1.75)$ & $(0.00)$ & $(100)$ \\
\hline Business & 14 & 00 & 00 & 14 \\
Persons & $(100)$ & $(0.00)$ & $(0.00)$ & $(100)$ \\
\hline Others & 67 & 05 & 04 & 76 \\
& $(88.16)$ & $(6.58)$ & $(5.26)$ & $(100)$ \\
\hline \multicolumn{1}{|c|}{ Total } & $\mathbf{2 7 0}$ & $\mathbf{1 1}$ & $\mathbf{0 6}$ & $\mathbf{2 8 7}$ \\
& $\mathbf{( 9 4 . . 0 8 )}$ & $\mathbf{( 3 . 8 3 )}$ & $\mathbf{( 2 . 0 9 )}$ & $\mathbf{( 1 0 0 )}$ \\
\hline
\end{tabular}

Source: Primary Data from Online Survey,

Note: Figures in parentheses indicates percentages

\section{Practice of Maintaining Social Distance by the Public}

The opinion of the respondents on maintaining social distancing by the public is observed that out of 14 government employees under review, 70.71\% opined that the public are also following the social distancing in the market and public places for selfprotection from COVID-19 (table 9 and diagram 9).

Figure 8: Using Mask outside the House

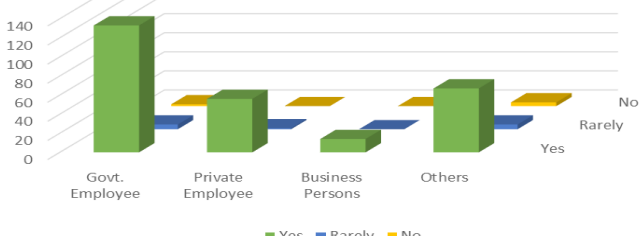

It may also observed that $64.91 \%$ of private employees observed that other people are also following social distancing. It reveals that $64.47 \%$ 
of business people informed that the public are following social distancing in the public places. Out of 287 respondents under review, $67.25 \%$ opined that the other people are also following social distancing in the public places and $32.75 \%$ informed that the people are not following the social distance to prevent COVID-19.

Table 9: Practice of Maintaining Social Distance by the Public

\begin{tabular}{|c|c|c|c|}
\hline Occupation & Yes & No & Total \\
\hline $\begin{array}{l}\text { Govt. } \\
\text { Employee }\end{array}$ & $\begin{array}{c}99 \\
(70.71)\end{array}$ & $\begin{array}{c}41 \\
(29.29)\end{array}$ & $\begin{array}{c}140 \\
(100)\end{array}$ \\
\hline $\begin{array}{l}\text { Private } \\
\text { Employee }\end{array}$ & $\begin{array}{c}37 \\
(64.91)\end{array}$ & $\begin{array}{c}20 \\
(35.09)\end{array}$ & $\begin{array}{c}57 \\
(100)\end{array}$ \\
\hline $\begin{array}{l}\text { Business } \\
\text { Persons }\end{array}$ & $\begin{array}{c}08 \\
(57.14)\end{array}$ & $\begin{array}{c}06 \\
(42.86)\end{array}$ & $\begin{array}{c}14 \\
(100)\end{array}$ \\
\hline Others & $\begin{array}{c}49 \\
(64.47)\end{array}$ & $\begin{array}{c}27 \\
(35.53)\end{array}$ & $\begin{array}{c}76 \\
(100)\end{array}$ \\
\hline Total & $\begin{array}{c}193 \\
(67.25)\end{array}$ & $\begin{array}{c}94 \\
(32.75)\end{array}$ & $\begin{array}{c}287 \\
(100)\end{array}$ \\
\hline
\end{tabular}

Source: Primary Data from Online Survey,

Note: Figures in parentheses indicates percentages

Figure 9: Practice of Maintaining Social Distance by the Public

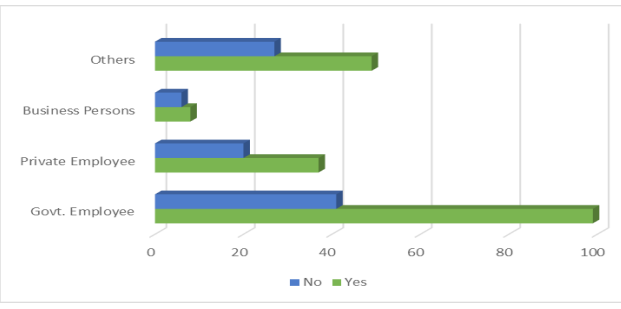

\section{Frequency of Using Sanitizer}

It reveals that $70 \%$ of the government employees, $64.91 \%$ of the private employees, $85.71 \%$ of the business persons and $76.32 \%$ of others are frequently using sanitizer to protect from Corona virus (table 120 and diagram 10). It may also noticed that $26.43 \%$ of the government employees, $33.33 \%$ of the private employees, $7.41 \%$ of the business persons and $22.37 \%$ of others are frequently using sanitizer. Only $3.57 \%$ of the government employees, $1.75 \%$ of private employees, $7.14 \%$ of business persons and another $1.32 \%$ of others are reported that they never applying sanitizer.
Table 10: Frequency of Using Sanitizer

\begin{tabular}{|l|c|c|c|c|}
\hline Occupation & Never & Occasionally & Regularly & Total \\
\hline Govt. & 05 & 37 & 98 & 140 \\
Employee & $(3.57)$ & $(26.43)$ & $(70.00)$ & $(100)$ \\
\hline Private & 01 & 19 & 37 & 57 \\
Employee & $(1.75)$ & $(33.33)$ & $(64.91)$ & $(100)$ \\
\hline Business & 01 & 01 & 12 & 14 \\
Persons & $(7.14)$ & $(7.14)$ & $(85.71)$ & $(100)$ \\
\hline Others & 01 & 17 & 58 & 76 \\
& $(1.32)$ & $(22.37)$ & $(76.32)$ & $(100)$ \\
\hline \multirow{2}{*}{ Total } & $\mathbf{0 8}$ & $\mathbf{7 4}$ & $\mathbf{2 0 5}$ & $\mathbf{2 8 4}$ \\
& $\mathbf{( 2 . 8 2 )}$ & $\mathbf{( 2 6 . 0 6 )}$ & $\mathbf{( 7 2 . 1 8 )}$ & $\mathbf{( 1 0 0 )}$ \\
\hline
\end{tabular}

Source: Primary Data from Online Survey,

Note: Figures in parentheses indicates percentages

Figure 10: Frequency of Using Sanitizer

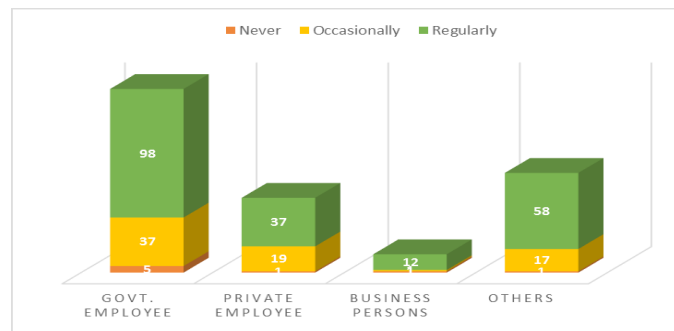

Classified Zones to Indicate Severity of COVID-19

To control and to inform the severity in the spread of COVID-19 and based on the spread of COVID-19 the areas are classified as green zone, orange zone and red zone. As shown in table 11 and diagram 11, $23.57 \%$ of government employees, $14.04 \%$ of private employees, $21.43 \%$ of business people, and $19.74 \%$ of others informed that their residential locations fall under green zone. About $44 \%$ of government employees, $36.84 \%$ of private employees, $35.71 \%$ of business people and 38.16 percent of others are living in orange zone areas. It may also reveals that $27.14 \%$ of government employees, $49.12 \%$ of private employees, $42.86 \%$ of business people and $42.11 \%$ of others are residing in red zone areas. It reveals that out of 287 respondents under study, $19.86 \%$ are in green zone, $42.51 \%$ are in orange zone and $36.24 \%$ are in red zone. 
Table 11: Classified Zone of the Respondents' Residential Area

\begin{tabular}{|l|c|c|c|c|}
\hline Occupation & $\begin{array}{c}\text { Green } \\
\text { Zone }\end{array}$ & $\begin{array}{c}\text { Orange } \\
\text { Zone }\end{array}$ & $\begin{array}{c}\text { Red } \\
\text { zone }\end{array}$ & Total \\
\hline $\begin{array}{l}\text { Govt. } \\
\text { Employee }\end{array}$ & $\begin{array}{c}33 \\
(23.57)\end{array}$ & $\begin{array}{c}62 \\
(44.29)\end{array}$ & $\begin{array}{c}38 \\
(27.14)\end{array}$ & $\begin{array}{c}140 \\
(100)\end{array}$ \\
\hline Private & 08 & 21 & 28 & 57 \\
Employee & $(14.04)$ & $(36.84)$ & $(49.12)$ & $(100)$ \\
\hline Business & 03 & 05 & 06 & 14 \\
Persons & $(21.43)$ & $(35.71)$ & $(42.86)$ & $(100)$ \\
\hline Others & 15 & 29 & 32 & 76 \\
& $(19.74)$ & $(38.16)$ & $(42.11)$ & $(100)$ \\
\hline \multicolumn{1}{|c|}{ Total } & $\begin{array}{c}\mathbf{5 7} \\
\mathbf{( 1 9 . 8 6 )}\end{array}$ & $\begin{array}{c}\mathbf{1 2 2} \\
\mathbf{( 4 2 . 5 1 )}\end{array}$ & $\begin{array}{c}\mathbf{1 0 4} \\
\mathbf{( 3 6 . 2 4 )}\end{array}$ & $\begin{array}{c}\mathbf{2 8 7} \\
\mathbf{1 0 0}\end{array}$ \\
\hline
\end{tabular}

Source: Primary Data from Online Survey,

Note: Figures in parentheses indicates percentages

Figure 11: Classified Zone of the Respondents' Residential Area

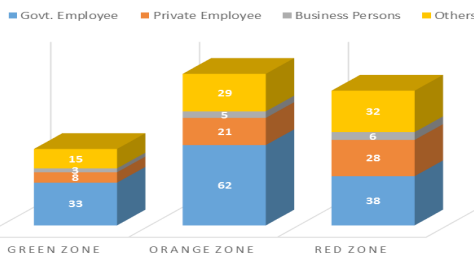

Bored of Staying Free during Lockdown Period at Home

It may be observed that $43.57 \%$ government employees, $43.86 \%$ of private employees, $64.29 \%$ of business persons and $60.53 \%$ of others informed that they are bored of staying at home during the lockdown period (table 12 and diagram 12). It reveals that $56.43 \%$ of government employees, $56.14 \%$ of private employees, $35.71 \%$ of business persons and $39.47 \%$ of others informed that they are not feeling bored due to stay at home during COVID-19 period.
Table 12: Bored of Staying Free during Lock-Down Period at Home

\begin{tabular}{|l|c|c|c|}
\hline Occupation & No & Yes & Total \\
\hline Govt. & 79 & 61 & 140 \\
Employee & $(56.43)$ & $(43.57)$ & $(100)$ \\
\hline Private & 32 & 25 & 57 \\
Employee & $(56.14)$ & $(43.86)$ & $(100)$ \\
\hline Business & 05 & 09 & 14 \\
Persons & $(35.71)$ & $(64.29)$ & $(100)$ \\
\hline Others & 30 & 46 & 76 \\
& $(39.47)$ & $(60.53)$ & $(100)$ \\
\hline \multicolumn{1}{|c|}{ Total } & $\mathbf{1 4 6}$ & $\mathbf{1 4 1}$ & $\mathbf{2 8 7}$ \\
& $\mathbf{( 5 0 . 8 7 )}$ & $\mathbf{( 4 9 . 1 3 )}$ & $\mathbf{( 1 0 0 )}$ \\
\hline
\end{tabular}

Source: Primary Data from Online Survey,

Note: Figures in parentheses indicates percentages

Figure 12: Bored of Staying Free during Lock-Down Period at Home

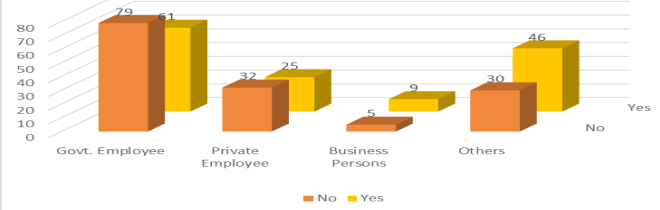

Way of Spending Time during Lockdown Period

It may be observed that out of 287 respondents, $52.26 \%$ of the respondents are watching TV during lockdown period. About $6 \%$ are informed that they are reading newspapers and books. $8.71 \%$ of the respondents spend their time with their children and other family members, $3.83 \%$ were helped in domestic works like cooking food, cleaning house etc. Another $12.89 \%$ were involved in their occupational duties from home and $16.03 \%$ spent their time by using WhatsApp / Facebook / internet games etc, (table 13 and diagram 13).

Table 13: Way of Spending Time during Lock -Down Period

\begin{tabular}{|c|c|c|c|c|c|c|c|}
\hline Occupation & $\begin{array}{c}\text { Watching } \\
\text { TV }\end{array}$ & $\begin{array}{c}\text { Reading } \\
\text { Newspapers } \\
\text { / Books }\end{array}$ & $\begin{array}{c}\text { Spending } \\
\text { Time with } \\
\text { Children/ } \\
\text { Family } \\
\text { Members }\end{array}$ & $\begin{array}{l}\text { Helping } \\
\text { in } \\
\text { Domestic } \\
\text { Works }\end{array}$ & $\begin{array}{c}\text { Occupational } \\
\text { Duties from } \\
\text { Home }\end{array}$ & $\begin{array}{c}\text { Using } \\
\text { WhatsApp / } \\
\text { Facebook } \\
\text { / Internet } \\
\text { Games }\end{array}$ & Total \\
\hline Govt. Employee & 81 & 07 & 11 & 05 & 19 & 17 & 140 \\
\hline$\%$ & 57.86 & 5.00 & 7.86 & 3.57 & 13.57 & 12.14 & 100 \\
\hline Private Employee & 18 & 05 & 06 & 03 & 17 & 08 & 57 \\
\hline$\%$ & 31.58 & 8.77 & 10.53 & 5.26 & 29.82 & 14.04 & 100 \\
\hline
\end{tabular}


International Journal of Arts, Science and Humanities

\begin{tabular}{|c|c|c|c|c|c|c|c|}
\hline Business Persons & 07 & 01 & 02 & 01 & 00 & 03 & 14 \\
\hline$\%$ & 50.00 & 7.14 & 14.29 & 7.14 & 0.00 & 21.43 & 100 \\
\hline Others & 44 & 05 & 06 & 02 & 01 & 18 & 76 \\
\hline$\%$ & 57.89 & 6.58 & 7.89 & 2.63 & 1.32 & 23.68 & 100 \\
\hline Total & 150 & 18 & 25 & 11 & 37 & 46 & 287 \\
\hline$\%$ & 52.26 & 6.27 & 8.71 & 3.83 & 12.89 & 16.03 & 100 \\
\hline
\end{tabular}

Source: Primary Data from Online Survey, Note: Figures in parentheses indicates percentages

It may also noticed that $57.86 \%$ of government employees, $31.58 \%$ of private employees, $50 \%$ of business persons and $57.89 \%$ of others spent their time by watching TV during lockdown period. About $5 \%$ of government employees, $8.77 \%$ of private employees, $7.14 \%$ of business people and $6.58 \%$ of others utilized their time during lockdown for reading newspapers and books, they interested. It may be observed that $7.86 \%$ of government employees, $10.53 \%$ of private employees, $14.29 \%$ of business people and $7.89 \%$ of others spent their time with their children and other family members.

Figure 13: Way of Spending Time during Lock -Down Period

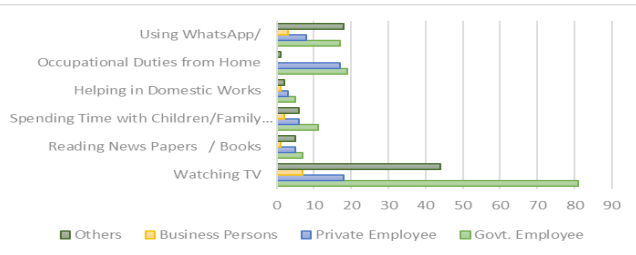

As shown in table $13,3.57 \%$ of government employees, $5.26 \%$ of private employees, $7.14 \%$ of business people and $2.63 \%$ of others helped their partners in cooking food, cleaning utensils, washing cloths and cleaning home etc., Another 13.57\% of government employees, $29.82 \%$ of private employees, and $1.32 \%$ of others involved in their occupational duties through work from home and $12.14 \%$ of government employees, $14.04 \%$ of private employees, $21.43 \%$ of business people and $16.03 \%$ of others spent their time by using WhatsApp/ Facebook / internet games etc.,

\section{Facing Mental Tension due to Stay at Home during Lockdown}

Due to lockdown, many persons in the society faced different problems as they spend their whole time at home such as mental tensions, fear about
COVID-19, loss of income and employment etc. It is observed that out of 287 respondents under review, $62.72 \%$ were faced mental tensions due to spending of their time at home lonely. On the other, $37.28 \%$ have no tensions even lockdown period (table 14 and diagram 14). It may also noticed that $63.57 \%$ of government employees, $64.91 \%$ of private employees, $35.71 \%$ of business people and $64.47 \%$ of others informed that they facing mental tensions due to their stay at home during lockdown period.

Table 14: Facing Mental Tension at Home due to Lock-Down

\begin{tabular}{|l|c|c|c|}
\hline Occupation & No & Yes & Total \\
\hline $\begin{array}{l}\text { Govt. } \\
\text { Employee }\end{array}$ & $\begin{array}{c}89 \\
(63.57)\end{array}$ & $\begin{array}{c}51 \\
(36.43)\end{array}$ & $\begin{array}{c}140 \\
(100)\end{array}$ \\
\hline Private & 37 & 20 & 57 \\
Employee & $(64.91)$ & $(35.09)$ & $(100)$ \\
\hline Business & 05 & 09 & 14 \\
Persons & $(35.71)$ & $(64.29)$ & $(100)$ \\
\hline Others & 49 & 27 & 76 \\
& $(64.47)$ & $(35.53)$ & $(100)$ \\
\hline \multicolumn{1}{|c|}{ Total } & $\mathbf{1 8 0}$ & $\mathbf{1 0 7}$ & $\mathbf{2 8 7}$ \\
& $\mathbf{( 6 2 . 7 2 )}$ & $\mathbf{( 3 7 . 2 8 )}$ & $\mathbf{( 1 0 0 )}$ \\
\hline
\end{tabular}

Source: Primary Data from Online Survey,

Note: Figures in parentheses indicates percentages

Figure 14: Facing Mental Tension at Home due to Lock-Down

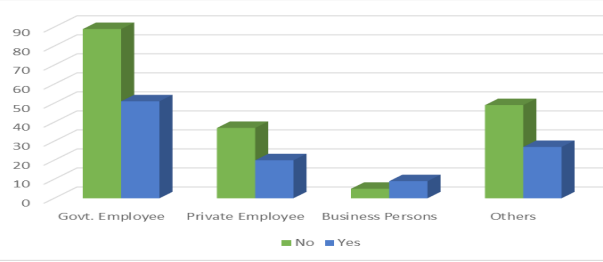

Opinion on the Willingness to Continue Lock-down

The people are facing many socio-economic problems in following lockdown even though it is 
one of the safe method to prevent COVID-19. To observe this, the opinion of the public has been collected on their willingness to continue lockdown for another 14 days of time. It shows that $84.12 \%$ of the total respondents are willing to continue lockdown as it is the only safe measure to control COVID-19 (table 15 and diagram 15).

Table 15: Willing to Continue Lockdown for another 2 Weeks

\begin{tabular}{|l|c|c|c|}
\hline Occupation & No & Yes & Total \\
\hline $\begin{array}{l}\text { Govt. } \\
\text { Employee }\end{array}$ & $\begin{array}{c}23 \\
(16.43)\end{array}$ & $\begin{array}{c}117 \\
(83.57)\end{array}$ & $\begin{array}{c}140 \\
(100)\end{array}$ \\
\hline Private & 08 & 49 & 57 \\
Employee & $(14.04)$ & $(85.96)$ & $(100)$ \\
\hline Business & 02 & 12 & 14 \\
Persons & $(14.29)$ & $(85.71)$ & $(100)$ \\
\hline Others & $\begin{array}{c}12 \\
(15.79)\end{array}$ & $\begin{array}{c}64 \\
(84.21)\end{array}$ & $\begin{array}{c}76 \\
(100)\end{array}$ \\
\hline \multicolumn{1}{|c|}{ Total } & $\mathbf{3 5}$ & $\mathbf{2 4 2}$ & $\mathbf{2 8 7}$ \\
& $(\mathbf{1 2 . 2 0})$ & $\mathbf{( 8 4 . 3 2 )}$ & $\mathbf{( 1 0 0 )}$ \\
\hline
\end{tabular}

Source: Primary Data from Online Survey,

Note: Figures in parentheses indicates percentages

\section{Figure 15: Willing to Continue Lockdown for} another 2 Weeks

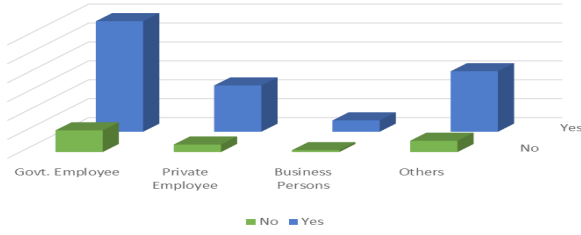

It may also noticed that $83.57 \%$ of government employees, $85.96 \%$ of private employees, $85.71 \%$ of business people and $84.21 \%$ of others expressed their willingness to continue lockdown in the country as well as in the state of Andhra Pradesh. It reveals that out of 287 respondents under review, $84.23 \%$ are expressed their willingness to continue lockdown and the remaining $12.20 \%$ expressed their dissatisfaction to continue lockdown as they are suffering with economic problems.

\section{Using BP Tablets for Hypertension}

Having hypertension is one of the health problem to face the corona virus. For this reason, we have been observed the using of BP tablets by the respondents to know the severity of attacking the
COVID-19 disease. It may be observed that out of 287 sample respondents, $33.10 \%$ are using BP tablets for hypertension (table 16 and diagram 16). It reveals that $30.71 \%$ of government employees, $28.07 \%$ of private employees, $50 \%$ of business people and $38.16 \%$ of others are using BP tablets for controlling hypertension. On the other, $69.29 \%$ of government employees, $71.93 \%$ of private employees, $50 \%$ of business people and $61.84 \%$ of others are not using BP tablets. It shows that there is a low possibility of attacking COVID-19 for these people.

Table 16: Using BP Tablets for Hypertension

\begin{tabular}{|l|c|c|c|}
\hline Occupation & No & Yes & Total \\
\hline $\begin{array}{l}\text { Govt. } \\
\text { Employee }\end{array}$ & $\begin{array}{c}97 \\
(69.29)\end{array}$ & $\begin{array}{c}43 \\
(30.71)\end{array}$ & $\begin{array}{c}140 \\
(100)\end{array}$ \\
\hline Private & 41 & 16 & 57 \\
Employee & $(71.93)$ & $(28.07)$ & $(100)$ \\
\hline Business & 07 & 07 & 14 \\
Persons & $(50.00)$ & $(50.00)$ & $(100)$ \\
\hline Others & 47 & 29 & 76 \\
& $(61.84)$ & $(38.16)$ & $(100)$ \\
\hline \multicolumn{1}{|c|}{ Total } & $\mathbf{1 9 2}$ & $\mathbf{9 5}$ & $\mathbf{2 8 7}$ \\
& $\mathbf{( 6 6 . 9 0 )}$ & $\mathbf{( 3 3 . 1 0 )}$ & $\mathbf{( 1 0 0 )}$ \\
\hline
\end{tabular}

Source: Primary Data from Online Survey,

Note: Figures in parentheses indicates percentages

\section{Figure 16: Using BP Tablets for Hypertension}

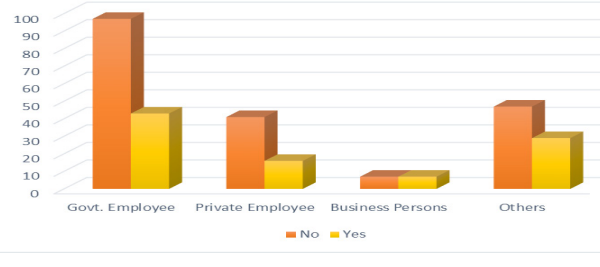

\section{Suffering from Malaria}

Suffering from malaria may also one of the reason for easy attack of corona virus. It is observed that out of 287 respondents, $19.51 \%$ informed that they suffered from malaria in their lifetime. About $11.85 \%$ observed that may be,l they suffered from Malaria and $68.64 \%$ informed that they were not suffered from Malaria (table 17 and diagram 17). It reveals that $10.17 \%$ of government employees, $12.28 \%$ of private employees, $11.84 \%$ of business people and $21.43 \%$ of others informed that may be, they suffered from Malaria. About $67.86 \%$ of government employees, $71.93 \%$ of private 
employees, $42.86 \%$ of business people and $72.37 \%$ of others informed that they have not been suffered from Malaria. It shows that $21.43 \%$ of government employees, $35.71 \%$ of business people, and $15.79 \%$ of others informed that they suffered from Malaria. It shows that the probability of attack of COVID-19 is less among the sample respondents under study.

Table 17: Have You Ever Suffered With Malaria

\begin{tabular}{|l|c|c|c|c|}
\hline Occupation & Maybe & No & Yes & Total \\
\hline Govt. & 15 & 95 & 30 & 140 \\
Employee & $(10.71)$ & $(67.86)$ & $(21.43)$ & $(100)$ \\
\hline Private & 07 & 41 & 09 & 57 \\
Employee & $(12.28)$ & $(71.93)$ & $(15.79)$ & $(100)$ \\
\hline Others & 03 & 06 & 05 & 14 \\
& $(21.43)$ & $(42.86)$ & $(35.71)$ & $(100)$ \\
\hline Business & 09 & 55 & 12 & 76 \\
Persons & $(11.84)$ & $(72.37)$ & $(15.79)$ & $(100)$ \\
\hline \multicolumn{1}{|c|}{ Total } & $\mathbf{3 4}$ & $\mathbf{1 9 7}$ & $\mathbf{5 6}$ & $\mathbf{2 8 7}$ \\
& $\mathbf{( 1 1 . 8 5 )}$ & $\mathbf{( 6 8 . 6 4 )}$ & $\mathbf{( 1 9 . 5 1 )}$ & $\mathbf{( 1 0 0 )}$ \\
\hline
\end{tabular}

Source: Primary Data from Online Survey,

Note: Figures in parentheses indicates percentages

Figure 17: Have You Ever Suffered With Malaria

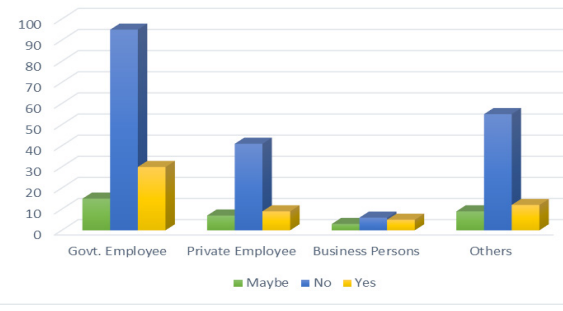

\section{BCG Vaccine Taken by Respondents}

As per the information from the medical science experts, spread of COVID-19 is low in the persons who have taken BCG vaccine. It is observed that out of 287 respondents, $21.60 \%$ of respondents informed that, may be, they have taken BCG vaccine and $35.54 \%$ of the respondents informed that they have taken BCG vaccine (table 18 and diagram 18).

Table 18 Have You Ever Taken BCG Vaccine

\begin{tabular}{|l|c|c|c|c|}
\hline Occupation & Maybe & No & Yes & Total \\
\hline Govt. & 26 & 65 & 49 & 140 \\
Employee & $(18.57)$ & $(46.43)$ & $(35.00)$ & $(100)$ \\
\hline Private & 12 & 25 & 20 & 57 \\
Employee & $(21.05)$ & $(43.86)$ & $(35.09)$ & $(100)$ \\
\hline
\end{tabular}

\begin{tabular}{|l|c|c|c|c|}
\hline $\begin{array}{l}\text { Business } \\
\text { Persons }\end{array}$ & $\begin{array}{c}05 \\
(35.71)\end{array}$ & $\begin{array}{c}02 \\
(14.29)\end{array}$ & $\begin{array}{c}07 \\
(50.00)\end{array}$ & $\begin{array}{c}14 \\
(100)\end{array}$ \\
\hline Others & 19 & 31 & 26 & 76 \\
& $(25.00)$ & $(40.79)$ & $(34.21)$ & $(100)$ \\
\hline \multirow{2}{*}{ Total } & $\mathbf{6 2}$ & $\mathbf{1 2 3}$ & $\mathbf{1 0 2}$ & $\mathbf{2 8 7}$ \\
& $\mathbf{( 2 1 . 6 0 )}$ & $\mathbf{( 4 2 . 8 6 )}$ & $\mathbf{( 3 5 . 5 4 )}$ & $\mathbf{( 1 0 0 )}$ \\
\hline
\end{tabular}

Source: Primary Data from Online Survey,

Note: Figures in parentheses indicates percentages

Figure 18: Have You Ever Taken BCG Vaccine

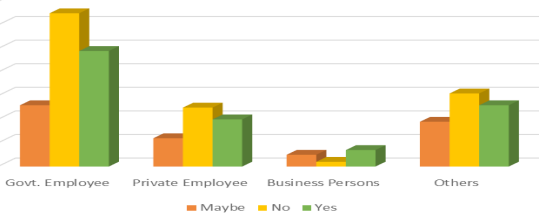

It is observed that about $35 \%$ of government and private employees each, $50 \%$ of business people and $34.21 \%$ others have taken BCG vaccine. It may also noticed that $18.57 \%$ of government employees, $21.05 \%$ of private employees, $35.71 \%$ of business people and $25 \%$ of others informed that, may be, they have taken $\mathrm{BCG}$ vaccine.

\section{Chronic Health problems of the Respondents}

During the lockdown period, there is no proper medical and health facilities to the public to consult the doctors for chronic health problems well as other health problems. It is observed that only $10.45 \%$ of the respondents have suffering from chronic health problems (table 19 and diagram 19). It reveals that $12.14 \%$ of government employees, $5.26 \%$ of private employees, $7.14 \%$ of business persons and $11.84 \%$ of others have suffering from chronic health problems and they are unable to visit the hospitals due to lockdown in the country.

\section{Consulting Doctors during Lockdown Period}

Many of the public who have suffered from health problems are unable to visit the hospitals in the lockdown period. The same is observed and presented in table 20 and illustrated in diagram 20. It reveals that only $16.72 \%$ were consulted the doctors, $17.77 \%$ of respondents informed that they tried to visit the doctors, but due to lockdown in the country, doctors were not available and another $65.51 \%$ of respondents informed that they have no need for immediate consultation with the doctors. 
Table 19: Chronic Health Problems of the Respondents

\begin{tabular}{|l|c|c|c|}
\hline Occupation & No & Yes & Total \\
\hline $\begin{array}{l}\text { Govt. } \\
\text { Employee }\end{array}$ & $\begin{array}{c}123 \\
(87.86)\end{array}$ & $\begin{array}{c}17 \\
(12.14)\end{array}$ & $\begin{array}{c}140 \\
(100)\end{array}$ \\
\hline Private & 53 & 03 & 57 \\
Employee & $(92.98)$ & $(5.26)$ & $(100)$ \\
\hline Business & 13 & 01 & 14 \\
Persons & $(92.86)$ & $(7.14)$ & $(100)$ \\
\hline Others & $\begin{array}{c}68 \\
(89.47)\end{array}$ & $\begin{array}{c}09 \\
(11.84)\end{array}$ & $\begin{array}{c}76 \\
(100)\end{array}$ \\
\hline \multicolumn{1}{|c|}{ Total } & $\begin{array}{c}\mathbf{2 5 7} \\
(\mathbf{8 9 . 5 5})\end{array}$ & $\begin{array}{c}\mathbf{3 0} \\
\mathbf{( 1 0 . 4 5 )}\end{array}$ & $\begin{array}{c}\mathbf{2 8 7} \\
\mathbf{( 1 0 0 )}\end{array}$ \\
\hline \multicolumn{2}{|c|}{}
\end{tabular}

Source: Primary Data from Online Survey

Figure 19: Chronic Health Problems of the Respondents

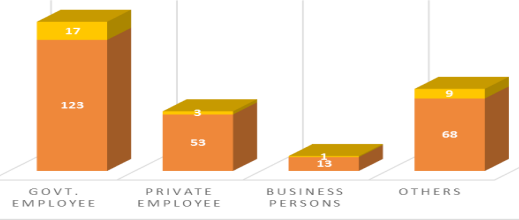

Figure 20: Consulting Doctors during COVID-19

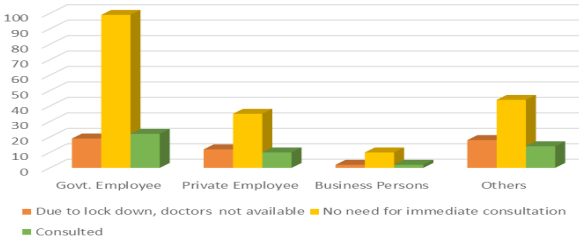

Table 20: Consulting Doctors during COVID-19

\begin{tabular}{|c|c|c|c|c|}
\hline 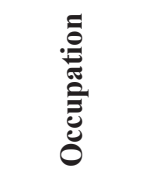 & 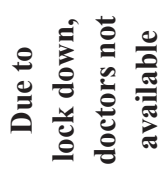 & 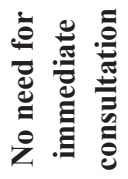 & 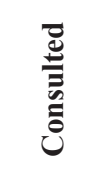 & 量 \\
\hline $\begin{array}{l}\text { Govt. } \\
\text { Employee }\end{array}$ & $\begin{array}{c}19 \\
(13.57)\end{array}$ & $\begin{array}{c}99 \\
(70.71)\end{array}$ & $\begin{array}{c}22 \\
(15.71)\end{array}$ & $\begin{array}{c}140 \\
(100)\end{array}$ \\
\hline $\begin{array}{l}\text { Private } \\
\text { Employee }\end{array}$ & $\begin{array}{c}12 \\
(21.05)\end{array}$ & $\begin{array}{c}35 \\
(61.40)\end{array}$ & $\begin{array}{c}10 \\
(17.54)\end{array}$ & $\begin{array}{c}57 \\
(100)\end{array}$ \\
\hline $\begin{array}{l}\text { Business } \\
\text { Persons }\end{array}$ & $\begin{array}{c}02 \\
(14.29)\end{array}$ & $\begin{array}{c}10 \\
(71.43)\end{array}$ & $\begin{array}{c}02 \\
(14.29)\end{array}$ & $\begin{array}{c}14 \\
(100)\end{array}$ \\
\hline Others & $\begin{array}{c}18 \\
(23.68)\end{array}$ & $\begin{array}{c}44 \\
(57.89)\end{array}$ & $\begin{array}{c}14 \\
(18.42)\end{array}$ & $\begin{array}{c}76 \\
(100)\end{array}$ \\
\hline Total & $\begin{array}{c}51 \\
(17.77)\end{array}$ & $\begin{array}{c}188 \\
(65.51)\end{array}$ & $\begin{array}{c}48 \\
(16.72)\end{array}$ & $\begin{array}{c}287 \\
(100)\end{array}$ \\
\hline
\end{tabular}

Source: Primary Data from Online Survey

\section{Food Consumption Behaviour of Respondents}

Due to insecurity from COVID-19, many of the population are taking care in their dietary habits. To know the care on food habits to prevent from corona, the data has been collected before and during the lockdown period on the food habits of respondents. It reveals that before COVID-19, $68.57 \%$ of government employees consumed normal food and during the lockdown period or during COVID-19, only $36.43 \%$ of government employees are taking normal food and they diverted to other food habits (tables 21, 22 and diagrams 21, 22).

Table 21: Food Consumption Behaviour of Respondents before COVID-19

\begin{tabular}{|l|c|c|c|c|c|c|}
\hline \multicolumn{1}{|c|}{ Occupation } & Normal Food & Brown Rice/ Millets & Non-Veg & Fruits & Snacks & Total \\
\hline Govt. Employee & $96(68.57)$ & $44(31.43)$ & $71(50.71)$ & $33(23.57)$ & $19(13.57)$ & $140(100)$ \\
\hline Private Employee & $41(71.93)$ & $16(28.07)$ & $25(43.86)$ & $11(19.30)$ & $09(15.79)$ & $57(100)$ \\
\hline Business Persons & $09(64.29)$ & $05(35.71)$ & $09(64.29)$ & $04(28.57)$ & $05(35.71)$ & $14(100)$ \\
\hline Others & $52(68.42)$ & $24(31.58)$ & $58(76.32)$ & $38(50.00)$ & $12(15.79)$ & $76(100)$ \\
\hline \multicolumn{1}{|c|}{ Total } & $\mathbf{1 9 8}(\mathbf{6 8 . 9 9})$ & $\mathbf{8 9 ( 3 1 . 0 1 )}$ & $\mathbf{1 6 3 ( 5 6 . 7 9 )}$ & $\mathbf{8 6 ( 2 9 . 9 7 )}$ & $\mathbf{4 5 ( 1 5 . 6 8 )}$ & $\mathbf{2 8 7}(\mathbf{1 0 0})$ \\
\hline
\end{tabular}

Source: Primary Data from Online Survey

Table 22: Food Consumption Behaviour of Respondents during COVID-19

\begin{tabular}{|l|c|c|c|c|c|c|}
\hline \multicolumn{1}{|c|}{ Occupation } & Normal Food & Brown Rice / Millets & Non-Veg & Fruits & Snacks & Total \\
\hline Govt. Employee & $51(36.43)$ & $89(63.57)$ & $62(44.29)$ & $68(48.57)$ & $48(34.29)$ & $140(100)$ \\
\hline Private Employee & $28(49.12)$ & $29(50.88)$ & $31(54.39)$ & $37(64.91)$ & $26(45.61)$ & $57(100)$ \\
\hline Business Persons & $04(28.57)$ & $10(71.43)$ & $12(85.71)$ & $06(42.86)$ & $09(64.29)$ & $14(100)$ \\
\hline Others & $28(36.84)$ & $48(63.16)$ & $63(82.89)$ & $58(76.32)$ & $27(35.53)$ & $76(100)$ \\
\hline \multicolumn{1}{|c|}{ Total } & $\mathbf{1 1 1}(\mathbf{3 8 . 6 8})$ & $\mathbf{1 7 6 ( 6 1 . 3 2 )}$ & $\mathbf{1 6 8 ( 5 8 . 5 4 )}$ & $\mathbf{1 6 9 ( 5 8 . 8 9 )}$ & $\mathbf{1 1 0 ( 3 8 . 3 3 )}$ & $\mathbf{2 8 7}(\mathbf{1 0 0})$ \\
\hline
\end{tabular}

Source: Primary Data from Online Survey 
It may also noticed that before COVID-19, $31.43 \%$ of government employees consumed brown rice and millets and during COVID-19 $63.57 \%$ of the government employees are consuming brown rice and millets. Before COVID-19 50.71\% of government employees included non-veg as one of the dietary item weekly and during COVID-19, only $44.29 \%$ of government employees are taking non-veg. Before COVID-19, 23.57\% of government employees have taken fruits along with regular food and during the COVID-19, $48.57 \%$ of them are taking fruits to increase immunity. Consumption of snacks by government employees before COVID-19 are only $13.57 \%$ and during COVID-19 their number increased to $34.29 \%$.

\section{Figure 21: Food Consumption Behaviour of Respondents before COVID-19}

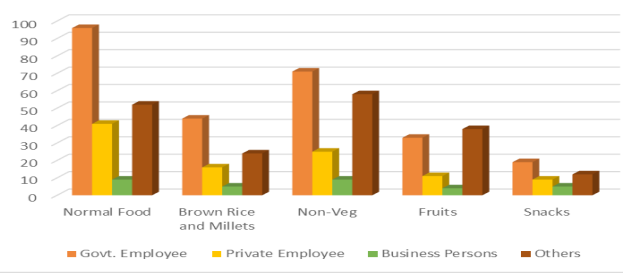

Figure 22: Food Consumption Behaviour of Respondents during COVID-19

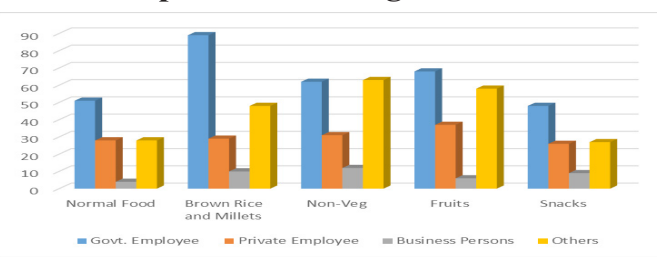

It may also observed that before COVID-19, $71.93 \%$ of private employees have taken normal food and during COVID-19 their percentage declined to $49.12 \%$ due to diversion in taking food. Before COVID-19, 28.07\% of private employees consumed brown rice and millets and during COVID-19, $50.88 \%$ are consuming brown rice and millets. Before COVID-19, $43.86 \%$ of private employees have taken non-veg along with their regular diet and during COVID-19, 54.39 percent of them are consuming non-veg. It reveals that before COVID-19, 19.30\% of private employees consumed fruits and during COVID-19, 64.91\% of them are consuming fruits. Before COVID-19, $15.79 \%$ of private employees consumed snacks and $45.61 \%$ are consuming snacks.
It reveals that before cOVID-19, 64.29\% of business people have taken normal food and during COVID-19, only $28.57 \%$ of business people are taking normal food. It shows that before COVID-19, $35.71 \%$ of business people have consumed brown rice and millets and during COVID-19, 71.43\% are consuming brown rice and millets. Before COVID-19 pandemic, $64.29 \%$ of business people consumed non-veg and during COVID-19, 85.71\% of them are consuming non-veg. Before COVID-19, fruits are consumed by $28.57 \%$ of business persons and $50 \%$ of others and during COVID- $19,42.86 \%$ of business persons and $76.82 \%$ of others are consuming fruits. It may also reveals that before COVID-19, snacks consumed by $35.71 \%$ of business persons and $15.79 \%$ of others and during COVID-19, snacks consumed by $64.29 \%$ of business people and $35.53 \%$ of others.

It may be observed that out of 287 respondents under study, before COVID-19, normal food taken by $68.99 \%$ of respondents, brown rice and millets taken by $31.01 \%$, non-veg consumed by $56.79 \%$ of respondents, fruits consumed by $29.97 \%$ of respondents and snacks as a diet by $15.68 \%$ of respondents. During COVID-19, normal food taken by $38.68 \%$, brown rice and millets taken by $61.32 \%$, non-veg as a diet by $58.54 \%$ of respondents, fruits are consuming by $58.89 \%$ of respondents and snacks as a diet by $38.33 \%$ of respondents. It shows that due to COVID-19, the food habits are changed by all the category of respondents to improve their immunity power to control COVID-19.

\section{Conclusions}

The developing country like India has been facing a variety of epidemics and pandemics from very early days. Various cases of influenza, cholera, dengue, smallpox and several others have been observed throughout the history of India. Only we have been able to eradicate some of them and many diseases still continue to pose a threat to the human population. It is not uncommon for sudden and rapid outbreaks happening in India and the main cause may be environmental problems, poor sanitary conditions, lack of proper public health system in many parts of the country. 
For various known and unknown conditions, now India is one of the worst sufferer from recent COVID-19. At the global level, many of the developed and developing countries are suffering from COVID-19. At the beginning of spread of COVID-19, India has been in safe place and recently India reaches to 4th place in COVID cases with $3,95,812$ cases against the total global level cases of $87,65,303$. To control Corona virus in the country, central and state governments have taken up various measures such as Janata Curfew, 5 Phases of lockdown, directed the public to wear Masks and use of sanitizers along with following social distancing to prevent from COVID-19. The article focused on the health problems of sample respondents, their food consumption behavior, measures taken to selfprotection from COVID-19.

Even though, the governments, media and experts are suggesting the public to follow lockdown, social distancing, wearing of masks, using sanitization and to avoid to come out from the homes unnecessarily, many of the public are not following the instructions. The people themselves to follow the precautionary measures to protect the spread of COVID-19. The shopkeepers are not providing proper sanitizers at the shops. To avoid the pandemic proper diet should be followed by the public themselves. The data for the present study has been collected at the 3rd phase of lockdown and received many positive issues from the public on COVID-19 pandemic. It is necessary to educate the public from NGOs, NSS and NCC cadres on prevention and self-protection from COVID-19 pandemic in the country.

\section{References}

Chandra, S. and Eva Kassens-Noor. "The Evolution of Pandemic Influenza: Evidence from India, 1918-19.” BMC Infectious Diseases, vol. 1, 2014.

COVID-19: Lockdown across India, in Line with WHO Guidance, UN News, 2020.

COVID-19 in India: Potential Impact of the Lockdown and Other Longer-Term Policies, Center for Disease Dynamics, Economics \& Policy (CDDEP), 2020.

Dikid, T. et al. "Emerging \& Re-Emerging Infections in India: An Overview." The Indian Journal of Medical Research, vol. 138, no. 1, 2013, pp. 19-31.

Dutt, Ashok K. et al. "Surat Plague of 1994, ReExamined." Southeast Asian Journal of Tropical Medicine and Public Health, vol. 37, no. 4, 2006, pp. 755-760.

Dutta, P.K. In Coronavirus Lockdown Extension, Modi Wields Stick, Offers Carrot on Exit Route, India Today, 2020.

Elsa, Evangeline. The Human Cost of India's Coronavirus Lockdown: Deaths by Hunger, Starvation, Suicide and More, Gulf News, 2020.

Full list of Red, Yellow, Green Zone districts for Lockdown 3.0, India Today, 2020.

Galwankar, S. and Angela Clem. "Swine Influenza A (H1N1), Strikes a Potential for Global Disaster." Journal of Emergencies, Trauma, and Shock, vol. 2, 2009, pp. 99-105.

Gettleman, Jeffrey and Kai Schultz. Modi Orders 3-Week Total Lockdown for All 1.3 Billion Indians, The New York Times, 2020.

Greenough, Paul. "Intimidation, Coercion and Resistance in the Final Stages of the South Asian Smallpox Eradication Campaign, 19731975." Social Science \& Medicine, vol. 41, no. 5 , 1995 , pp. $633-645$.

Gupta, Manohar Lal and Anuradha Sharma. "Pneumonic Plague, Northern India, 2002." Emerging Infectious Diseases, vol. 13, no. 4, 2007, pp. 664-666.

'I was Extremely Hurt...': Key Highlights of PM Modi's Mann Ki Baat address, Hindusthan Times, 2020.

Kaur, P. et al. "Chikungunya Outbreak, South India, 2006." Emerging Infectious Disease, vol. 14, no. 10, 2008, pp. 1623-1625.

Kumar, A. and A.S. Anoop Kumar. "Deadly Nipah Outbreak in Kerala: Lessons Learned for the Future." Indian Journal of Critical Care Medicine, vol. 22, no. 7, 2018, pp. 475-476.

Laxminarayan, Ramanan. What India Needs to Fight the Virus, The New York Times, 2020.

Lockdown 4.0 Guidelines, What's Allowed and what's Not?, The Hindu, 2020.

Pabhakar, N. et al. "The Epidemiology and Prevention of Poliomyelitis in a Rural Community in 
South India." Indian Pediatrics, vol. 18, no. 8, Singh, N.P. et al. "The 2003 Outbreak of Dengue 1981, pp. 527-532.

PM Modi Speech on Coronavirus Highlights: Janata Curfew on Sunday, Avoid Panic Buying, News 18, 2020.

RBI Cuts Rates, Allows Moratorium on Auto, Home Loan EMIs, The Hindu, 2020.

Sharma, Neeta. "Unlock 1": Malls, Restaurants, Places of Worship to Reopen June 8, NDTV, 2020. Fever in Delhi, India." The Southeast Asian Journal of Tropical Medicine and Public Health, vol. 36, no. 5, 2005, pp. 1174-1178.

Summary Table of SARS Cases by Country, WHO, 2003.

Tripathi, Rahul. India 21-Day Lockdown: What's Exempted, What's not, The Economic Times, 2020.

\section{Author Details}

Sai Charan Konanki, Data Scientist, School of Public Health, Harvard University, Boston, USA,

Email ID: saicharanhere@gmail.com

K Dasaratharamaiah, Professor, Department of Economics and Applied Economics, Sri Krishnadevaraya University, Ananthapuramu, Andhara Pradesh, India, Email ID: dasarath_91@yahoo.com 